\title{
Psychiatric Disorders among Hospitalized Women at the Psychiatry Hospital « Ibn Nafis Hospital » of Mohammed VI University Hospital Center
}

\author{
M. Rabitateddine*, S. Elfellah, S. Ennazk, I. Adali, F. Manoudi, F. Asri
}

Research Team for Mental Health, Mohammed VI University Hospital Center; Marrakesh, Morocco

DOI: $10.36347 /$ simcr.2020.v08i02.011

| Received: 28.01.2020 | Accepted: 04.02.2020 | Published: 12.02 .2020

*Corresponding author: M. Rabitateddine

Abstract

Original Research Article

Women get hospitalized for various serious mental disorders that are gender specific, half of them married with children, the other half singleldivorced women stigmatized and marginalized in our society. The aim of this study is to describe mentally ill women admitted into the psychiatric hospital, socio demographically and clinically, highlighting differences, specificities and multiple roles distress deviate with the course of disorder. It's a cross-sectional prospective study about 70 patients admitted at the psychiatry hospital Ibn Nafis on Mohammed VI university hospital Center in Marrakesh-Morocco, and reports the following results: The average age is 37,4 years, $44 \%$ of them are single, with a low educational level (primary school) $32,8 \% .64 \%$ of our women are from the urban region, $51,4 \%$ are jobless and $59 \%$ brought to the hospital by their families. $11,6 \%$ of patients in our study have positive family history, $70 \%$ of them suffered from paranoid schizophrenia. 55\% of patients are admitted for schizophrenia, followed by bipolar I disorder 18\%, Major depressive disorder affected $8 \%$ of our patients. $20 \%$ deal with a toxic habits, $14,5 \%$ abuse nicotine (74\% low dependence FTND) and one woman have tried quitting. The criminal was $5,7 \%$ including different psychiatric disorders involved, assault is the most common charge. Suicide attempts are closely linked to major depressive episodes of MDD and BID, in patients were already under a combination of antidepressants and anxiolytics for at least 3 months. Psychotic features are observed in most of admitted disorders, 83\% in BIP and 67\% in MDD. According to HAMILTON-DEPRESSION $66.3 \%$ of women are admitted for a severe depressive episode, $50 \%$ present anxiety comorbidity and a history of CBT sessions months prior hospitalization. Shading the light into admitted women in psychiatry and deciphering specific demographic, clinical and therapeutic features may improve the global care system and women's adherence to treatment and follow up.

Keywords: Hospitalized women - Schizophrenia - Major depressive disorder - Bipolar disorder I.

Copyright @ 2020: This is an open-access article distributed under the terms of the Creative Commons Attribution license which permits unrestricted use, distribution, and reproduction in any medium for non-commercial use (NonCommercial, or CC-BY-NC) provided the original author and source are credited.

\section{INTRODUCTION}

Within mental health services, there are fewer women than men with severe mental disorders, and there is evidence that their needs are relatively neglected resulting in specific deleterious effects. In research, as in services, the abilities of women with serious mental health problems appear to be underestimated, and there is almost a total absence of research into the views and experiences of such women. For example, such women are particularly vulnerable to sexual exploitation and violence, sexually transmitted diseases, unwanted pregnancies and loss of children's custody. Within general dearth of literature concerning the problems and needs of women with mental illness, there is almost complete absence of attention into the perspectives of women themselves. Like their male counterparts, such women are often considered too cognitively and emotionally impaired to be able to meaningfully express their views. Women want more women only space, a choice of skillful staff, an interactive environment, privacy and access to someone to talk to as an adult. Many mental disorders disrupt the peaceful lives of women, operating in different presentations: bipolar disorders, schizophrenia and other psychoses, depression, dementia and others [1]. The statistics are expanding worldwide. 60 million are diagnosed with bipolar disorders, 23 million with schizophrenia and over 50 million with dementia. Depression is considered women's number one morbidity (after cardio-vascular disorders), and these numbers consolidate the hypotheses of sex differences regarding mental disorders, specifically psychotic disorders, anxiety and substance abuse. In the twenty- 
first century, where health goals have shifted to increasing disability-free years of life rather than only to increasing life expectancy, mental disorders become more considerable, representing $12 \%$ of the global burden of disease, a number that is anticipated to rise to $15 \%$ by 2020 [2]. The increasing importance is combined by the fact that the weight of burden from these disorders has been increasing over the past decades. Moreover, although mental disorders are not listed as underlying causes of death on death certificates, they are associated with marked excess mortality, from chronic diseases. Thus, their impact on global health tends to be underestimated [3]. Two points deserve special emphasis for the future: health systems need to better respond to the needs of mentally ill women, this concerns not only the treatment gap but also other interventions needed for the people affected, and research is needed to best tailor such interventions in a cost effective and culturally acceptable manner [3].

\section{Aims OF THE STUDY}

- To determine the socio-demographic profiles of our inpatients.

To determine the prevalence of mental disorders among hospitalized patients interviewed at Ibn Nafis hospital.

- To assess the severity of the disorders using multiple scales.

\section{PATIENTS AND METHODS \\ Study Type and Patients}

A cross-sectional descriptive study concerning a sample of 70 female inpatient hospitalized at the psychiatry department IBN NAFIS in Marrakech, during the period: from January 2019 to June 2019.

\section{Inclusion Criteria}

- Women's consent after explaining the aim of our study.

- Female inpatients hospitalized at IBN NAFIS hospital.

\section{Exclusion Criteria}

- Lack of consent.

- Women admitted at the psychiatric emergencies but released the day after.

- Aggressive or sedated women who are unable to maintain the evaluation

\section{The Course of the Investigation}

Data collection was done following an interview with hospitalized women at the psychiatry department IBN NAFIS following their mental disorders during a six months period, inpatients were interrogated after their consent and explanation of the study's aim, by third and fourth year psychiatry residents.

\section{Ethical Considerations}

Recruited patients were informed of the aim of the study, only adherent patients after free consent were recruited. Data collection was executed anonymously, respecting patients' confidentiality.

\section{Statistical Method}

- The data are recorded in a questionnaire sheet

- Descriptive statistics are the primary focus of this analysis. Numeric data are presented by the following descriptive statistics as most appropriate: mean, median, standard deviation, range. Categorical data we represented by frequency tables: count and percentage.

- Descriptive data are analyzed using Microsoft Excel 2016.

\section{The Questionnaire}

A questionnaire was elaborated at psychiatry department (Ibn nafis hospital) using references such as the PANSS, HAMILTON Anxiety rating scale (HAMA), HAMILTION Depression rating scale (HAM-D), Fagerstrom Test for Nicotine Dependence (FTND). The questions were written in English and explained to inpatients in Arabic dialectal.

\section{RESUlTS \\ Descriptive Study \\ Demographic Data}

The average age in our case series is 37,61 years, with a minimum of 18 years and a maximum age of 60 years. $44,8 \%$ of patients are single with, $53 \%$ have no children, $5,71 \%$ are single mothers. $32,85 \%$ of inpatient in our study dropped out of primary school regardless of specific mental disorder, and jobless in $51,42 \%$. The $2 / 3$ of patients have a low economical level. To mention, a low level was determined with an income that doesn't exceed 2000dh per month. Regardless of admitted mental disorders, the urban area predominated (2/3). $59 \%$ of our patients were addressed by their families. 


\section{Overall Table-1: Socio-demographic characteristics of our case series.}

Overill table E Soclo-demographic characteristo of our case urites.

\begin{tabular}{|c|c|c|}
\hline Characteristic: & Frequency & Percentage \\
\hline $\begin{array}{l}\text { Marital Matus: } \\
\text { - Sngle } \\
\text { Married } \\
\text { Dinorced } \\
\text { Wdow }\end{array}$ & $\begin{array}{l}31 \\
25 \\
13 \\
1\end{array}$ & $\begin{array}{l}44,28 x \\
19,71 \mathrm{x} \\
18,75 \mathrm{n} \\
1,42 \mathrm{n}\end{array}$ \\
\hline $\begin{array}{l}\text { Presence of children: } \\
\text { Yes } \\
\text { No }\end{array}$ & $\begin{array}{l}33 \\
37 \\
\end{array}$ & $\begin{array}{l}47,14 \pi \\
52,65 x\end{array}$ \\
\hline $\begin{array}{l}\text { Tofession: } \\
\text { Lnmplaynd } \\
\text { Houswile } \\
\text { Studnnt } \\
\text { Oflice worker } \\
\text { Lberal worker } \\
\text { Farmer }\end{array}$ & $\begin{array}{l}36 \\
21 \\
2 \\
7 \\
8 \\
1\end{array}$ & $\begin{array}{c}51,42 \mathrm{M} \\
30 \mathrm{x} \\
2,8 \mathrm{x} \\
2,8 \mathrm{x} \\
11,42 \mathrm{M} \\
1,42 \mathrm{X}\end{array}$ \\
\hline $\begin{array}{l}\text { Econonicil hevel: } \\
\text { - Low } \\
\text { - Modium } \\
\text { High }\end{array}$ & $\begin{array}{l}47 \\
20 \\
3\end{array}$ & $\begin{array}{l}67,44 \\
28,75 x \\
4,26 x\end{array}$ \\
\hline $\begin{array}{l}\text { Educational level: } \\
\text { Uniducatind } \\
\text { Primary school } \\
\text { Muddle schoed } \\
\text { High school } \\
\text { Uninersity }\end{array}$ & $\begin{array}{c}9 \\
29 \\
17 \\
16 \\
5\end{array}$ & $\begin{array}{c}12, \mathrm{BSM} \\
32, \mathrm{BSM} \\
24,2 \mathrm{am} \\
22, \mathrm{BSN} \\
7,14 \mathrm{M} \\
\end{array}$ \\
\hline $\begin{array}{l}\text { Orgin: } \\
\text { Pural } \\
\text { Uirban }\end{array}$ & $\begin{array}{l}25 \\
45 \\
\end{array}$ & $\begin{array}{l}64.264 \\
19.71 x\end{array}$ \\
\hline $\begin{array}{l}\text { patents addrased by: } \\
\text { Alone } \\
\text { Family } \\
\text { pyychiatrist } \\
\text { police }\end{array}$ & $\begin{array}{c}6 \\
41 \\
3 \\
20\end{array}$ & 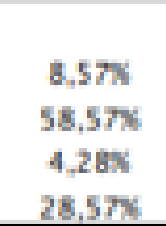 \\
\hline
\end{tabular}

\section{Family History}

$11,6 \%$ of Patients have positive family history of psychiatric disorders and only $3 \%$ of them were under treatment. In our study, only women admitted for MDD and schizophrenia have psychiatric family history. $70 \%$ of the patients with positive family psychiatric history have schizophrenia. The other $30 \%$ wasn't specified.

\section{Personal History}

The toxic history is the most represented in our case series $20 \%$. Medical history is represented by epilepsy, heart failure, lupus and asthma. The four women with epilepsy have schizophrenia as a mental disorder. Women with lupus, heart failure and asthma are hospitalized for Major depressive disorder with psychotic features. Criminal record is an important feature to search for in psychiatry. Table II is an abstarct to the creminal record's results in our study. Our results highlighted $55 \%$ of patients have paranoid schizophrenia. 5 other mental disorders were observed once during this case series: Bipolar II disorder, Schizophreniform disorder, substance induced psychotic disorder, delusional disorder and depressive disorder due to another medical condition (lupus and heart failure). In the last four years, $44,3 \%$ of patients have been diagnosed with mental illness (Table- 3 ) 
Table-2: Patient's specific criminal record

\begin{tabular}{c|c|c|c|c|c|}
\hline Mental dlsorder & $\begin{array}{c}\text { Number of } \\
\text { Incarceratlons }\end{array}$ & $\begin{array}{c}\text { Average perlod } \\
\text { of Incarceratlon }\end{array}$ & Season & $\begin{array}{c}\text { Date regarding } \\
\text { the Illness }\end{array}$ & Charges \\
\hline $\begin{array}{c}\text { Schizoaffective } \\
\text { disorder }\end{array}$ & 1 & 24 months & Winter & Simultaneously & Assault \\
\hline Bipolar I disorder & 2 & 6 months & Spring & Simultaneously & $\begin{array}{c}\text { Assault and } \\
\text { prostitution }\end{array}$ \\
\hline $\begin{array}{c}\text { Bipolar I disorder } \\
\text { Major depressive } \\
\text { disorder }\end{array}$ & 1 & 3 months & Summer & After & Drug \\
charges
\end{tabular}

Patients with psychosis spend more time indoors of psychiatric facilities 13,2 days more than non-psychosis patients. Dividing patients into these two categories is helpful when discussing results with literature findings. The non-psychosis category is observed to be admitted twice versus 2,5 for the psychosis group. There is a performance indicators at Ibn Nafis hospital from first January to the 31st of May (Table-5). 57,1\% of our patients continued to show on outdoor consultations and $15,7 \%$ of women have attempted suicide using: drowning, slitting wrists and poisoning.

Table-3: Seniority of psychiatric history

\begin{tabular}{c|c|c|c|c|}
\cline { 2 - 5 } & ALOS & OR & RI & LOS \\
\hline Women & $\mathbf{1 9 , 2}$ & $\mathbf{7 3 \%}$ & $\mathbf{5 , 7}$ & $\mathbf{3 8 5 9}$ \\
\hline Men & 23 & $96,7 \%$ & 6,2 & 21970 \\
\hline
\end{tabular}

About substance abuse, Cigarettes are the most frequent toxic with a rate of $14,5 \%$. The cannabis abuse rate is $12,5 \%$. Low nicotine dependence according to FTND rating scale was observed among $74 \%(n=11)$ of our patients, with a period of using varying between 3 and 7 years for $38 \%$ of our patients who have been using toxics. $23 \%(n=6)$ of our patients developed a toxic habit after being diagnosed, $43 \%$ had the toxic habit prior the mental disorder and only one patient tried to quit the toxic behavior, alone. No institution was involved.

Clinical data regarding mental disorders:

Table-4: Performance indicators at ibn nafis hospital from january 1st to May 31th

\begin{tabular}{|c|c|c|}
\hline Age group In years & Frequency & Percentage \\
\hline$<\mathbf{4}$ & $\mathbf{3 1}$ & $\mathbf{4 4 , 3 \%}$ \\
\hline $5-10$ & 19 & $27,1 \%$ \\
\hline $11-20$ & 16 & $22,8 \%$ \\
\hline$>20$ & 4 & $5,7 \%$ \\
\hline
\end{tabular}

Brief psychotic disorder (BPD) represents $7,1 \%$ of the total inpatients included in our case series. $60 \%$ of them were under no treatment in the last six months prior to their hospitalization. $40 \%$ of BPD inpatients are under a combination of antipsychotics and anxiolytics. $76,3 \%$ of our case series have a progressive (>6 months) onset of schizophrenia. $81,6 \%$ of admitted women with schizophrenia diagnosis are on multiple episodes, currently in acute episode status. Moderate positive psychotic symptoms were observed among $44 \%$ of patients and Mild negative symptoms were observed among $50 \%$ of them. $50 \%$ of patients suffering from Schizophrenia were under treatment (antipsychotics) in the last 6 months before hospitalization. $80 \%$ of Patients having Schizoaffective disorder in our case series have a progressive onset of the disorder. $60 \%$ of them were priorly under antipsychotic treatment (6 months), to highlight, none of them was under antidepressants nor antiparkinsonians. $8,3 \%$ of inpatients diagnosed with bipolar I disorder presented a major depressive episode. $91,6 \%$ was on a maniac episode. One case of bipolar II disorder was admitted during our study period. $83,3 \%$ of patients admitted for Bipolar I got into the psychiatric hospital with psychotic features, 58,3\% have co-occuring comobidity. Inpatient women diagnosed with major depressive disorder represent $9 \%$ of the total hospitalized rate, $67 \%$ of them have co-occuring 
psychotic features and $50 \%$ have melancolic features. Major depressive disorder with positive co-occurring comorbidity are $50 \%$ of all our serie case patients. According to the severity rating scale of depression HAMILTON-D, $66,3 \%$ of major depressive disorder inpatients are admitted for a severe major depressive episode. And $33,7 \%$ have a moderate one. And according to the severity rating scale of anxiety HAMILTON-A, $50 \%$ of major depressive disorder inpatients are admitted for a moderate general anxiety episode and $16,7 \%$ have a mild one. Patients suffering from MDD had been using antidepressants and axiolytics, and $66,6 \%$ had benefited from cognitive behavioral therapy (CBT).

\section{DisCUSSION}

\section{Demoraphic Data}

Table-5: Educational status among hospitalized women

\begin{tabular}{c|c|c|c|c|c}
\hline Authors & $\begin{array}{c}\text { Year of } \\
\text { study }\end{array}$ & Country & $\begin{array}{c}\text { Primary school } \\
\text { percentage }\end{array}$ & $\begin{array}{c}\text { Mlddle school } \\
\text { percentage }\end{array}$ & University \\
\hline Aro S et al & 1995 & $\begin{array}{c}\text { Finland } \\
\text { (Helsinki) }\end{array}$ & $46,4 \%$ & $42,2 \%$ & $11,5 \%$ \\
\hline Cloitre M et al & 1996 & USA (NYC) & \multicolumn{2}{|c|}{$33 \%$} & $31 \%$ \\
\hline Moussaoui D et al & 2016 & $\begin{array}{c}\text { Morocco } \\
\text { (Casablanca) }\end{array}$ & $31 \%$ & $36,3 \%$ & $12,1 \%$ \\
\hline Our study & 2019 & $\begin{array}{c}\text { Morocco } \\
\text { (Marrakech) }\end{array}$ & $32,8 \%$ & $24 \%$ & $7,1 \%$ \\
\hline
\end{tabular}

The average age in our case series is 37,6 years, with a minimum of 18 and a maximum age of 60 years. The age group between 41 and 49 years is the most represented in our sample $(30 \%)$. Thus this demographic particularity is close to the one found in the Ibn Rochd study Belghazi et al., [4] who's average age was 33,4 years. Similarly to our most represented range group, Furegato F et al., [5] found out that the 4049 group of female inpatients is the most represented. $44,2 \%$, when our patients were single, and married women were $35,7 \%$ of our case series and only 18,7 were divorced. Similarly to our finding, Cloitre et al., [6] and Belghazi et al., [4] had single women as a majority in their case series. On the contrary, Cochrane R et al., [7] and El Sayed et al., [8] had married women predominating, followed by single women on the second line. The high rate of celibacy in our study can be attributed to the early onset of mental disorders among the majority of hospitalized women, when patients with late onset have an overlapping proneness to marry and procreate [9]. Also, the poor prognosis of psychotic group of disorders and their great severity (high LOS, residual features, poo functioning) reduce chances of being in a relationship and starting a family. Our study sample $(\mathrm{n}=70)$ is smaller comparing to USA and UK studies conducted on larger populations, and so distorted results $[9,10]$. In our study, the majority of our patients dropped out in primary school period $32,8 \%$, followed by $24,8 \%$ dropped in middle school, and only 7,1\% attended the university. The table below elucidates our 2019 results, Moussaoui D et al., and other results of developed countries. Prevalence of psychiatric disorders in illiterate women is high, while being educated could be a protective factor against mental disorders. This could be attributed to sociocultural limitations among women with lower literacy status, which makes them unable to use more efficient coping styles to deal with stress $[11,12]$.

The population admitted at Ibn Nafis hospital has a very lower economical level which explains the poor educational level of our small sample (non representative). Half of our case series women are jobless $(51,4 \%),(30 \%)$ are housewives and only $(15,6 \%)$ are employed. These results are different than Comacchio's C et al., [13], where 34, 7\% are employed, $36,1 \%$ are housewives and $29,2 \%$ are unemployed. The Mediterranean-arab culture in both countries explains the high rate of housewives and working women are still a wreckage.

\section{Family History}

In our study, $11,6 \%$ of patients have positive history of mental illness, $70 \%$ of them have schizophrenia and other psychotic disorders. Our results join the literature with a rate that vary between $5,5 \%$ and $12,5 \%$. (Table-5) [14-19].

Table-6: Positive family history of schizophrenia spectrum and other psychotic disorders

\begin{tabular}{|c|c|c|c|}
\hline Authors & Year of study & Country & $\begin{array}{c}\text { Frequency of posittve } \\
\text { famlly history }\end{array}$ \\
\hline Bromderger J et al & 2016 & USA & 9,7 \\
\hline Our study & 2019 & Morocco & 3,48 \\
\hline
\end{tabular}


Genetic explaination of schizophrenia involves rare, common and novo risk alleles existing in a large number of genes. Despite substantial genetic heterogeneity, different classes of mutation have been shown to converge onto common biological pathways, implicating neuronal calcium signaling, synaptic plasticity and the immune system in the disorder. Also, schizophrenia shares risk alleles with other neuropsychiatric disorders with evidence of a gradient of mutational severity with intellectual disability and schizophrenia at the most extreme and moderate ends of this spectrum [20].

Table-7: Positive family history of major depressive disorder

\begin{tabular}{|c|c|c|c}
\hline Authors & Year of study & Country & $\begin{array}{c}\text { Frequency of posittve } \\
\text { famlly hlstory }\end{array}$ \\
\hline Albus and Maier & 1995 & Germany & $7,8 \%$ \\
\hline Alda et al & 1996 & Canada & $6 \%$ \\
\hline Konnecke et al & 2000 & Germany & $12,5 \%$ \\
\hline Arajarvi et al & 2006 & Finland & $9,6 \%$ \\
\hline Adachi et al & 2008 & Japan & $5,5 \%$ \\
\hline Our study & 2019 & Morocco & $\mathbf{8 , 1 2 \%}$ \\
\hline
\end{tabular}

Heritability of mood disorders is about $50 \%$, which means that genes alone are not sufficient to explain all the cases. But they confer a substantial risk which is combined with environmental stressors to determine the final illness, but which are these genes and why they confer the risk for more disorders? It is very interesting to see that many of those genes are linked to neuroplasticity and inflammation; two mechanisms that can be combined and decrease the possibility of the brain's possibility to react and be plastic to external stressors $[20,21]$.

\section{Personnal History}

$5,7 \%$ of women in our study have a criminal record with charges of mostly assault, then drug charges and a case of prostitution and homicide. Rossegger's finding [22] highlights homicide at first with $37,5 \%$, arson $31,3 \%$ and assault $12,5 \%$. The high rate of homicide can be related to access to firearms, high rate of substance abuse, personality disorders or a severe state of mental disorder. Conversely, mentally ill patients are overrepresented in the criminal justice system. This over representation has become a growing concern internationally among mental health workers, corrections departments, lawyers, public policy makers, and human rights attornies. Although, only 14 to $16 \%$ of people in the criminal justice system have a serious or persistent mental disorder. Skinner et al., [23] noted that $30 \%$ of people with mental illness will have a problem with alcohol and drug use in their lifetime and $37 \%$ of people who with alcohol issues, will develop a mental illness. This disparity is found in studies of the prevalence of drug use among patients with a first episode of psychosis. Thus, it reaches $74 \%$ in the study of Lambert et al., [24] against 23\% in that of Sevy et al., Our study joins Sevy et al., findings with $20 \%$. $14,5 \%$ of women use cigarettes, $12,5 \%$ use cannabis and 8,6 have alcohol abuse [23-26].

\section{Clinical Data Regarding Mental Disorders}

A specific distribution of mental disorders observed among hospitalized women underlines the predominance of schizophrenia with $55 \%$, bipolar I disorder $17 \%$ and MDD $8 \%$. These results vary in Belghazi et al., in spite of close geography and being it a recent Moroccan study too (Table-8) [4, 6, 13].

Table-8: Rate of schizophrenia among hospitalized women

\begin{tabular}{|c|c|}
\hline Perlod of studles & Schlzophrenla rate \\
\hline $1875-1924$ & $54 \%$ \\
\hline $1994-2010$ & $56 \%$ \\
\hline Our study (2019) & $55 \%$ \\
\hline
\end{tabular}

Newman et al., [27] point factors associated with lengthier stays: accommodation status (including living in supported accommodation, nursing/healthcare, and being homeless), being male, being unemployed/housewives and having a higher number of different care coordinators. On the other hand, factors associated with shorter stays are being a council tenant, having a diagnosis of a disorder due to psychoactive substance abuse (it correlates with our finding $\mathrm{LOS}=4$ days), affective disorders (it matches our findings LOS= 
9,7 days), stress-related and personality disorders. Marital status is not significant in this model. Tulloch et al., [28] conducted on a similar sample found no effect of unemployment on LOS. Newman L et al., [27] sample (7653) was larger than theirs (4485) which may have increased the power necessary to detect an effect in a sample where the majority is unemployed. The reason for this discrepancy needs to be explored further, and might underline the idea that these predictors of LOS are likely to be temporally, as well as locality, specific [29]. Inpatient women discharged from psychiatric facilities require timely follow-up care to maintain their functioning and avoid or delay future hospitalizations. Despite the importance of follow-up care, there is surprisingly little percentage that is adherent to outdoor appointments and psychotherapylgroup therapy sessions $(57,1 \%)$. These findings serve as a benchmark from which to measure progress. Given that our findings are based on a small sample $(n=70)$, we cannot fully explain the small rate of positive follow-up. Some variations could be attributable to cultural differences, religious superstitions across the region, or the availability of primary caregivers who accept to be in charge of the follow-up care. The high prevalence of co-occurring substance use disorders among women with severe mental illness is now widely recognized. As patients with dual-disorders have poor short-term outcomes in traditional mental health programs and do not readily fit into traditional substance abuse treatment programs [30], models that integrate mental health and substance abuse treatments have been developed [31]. Suicide has a strong association with mental disorders and contributes to the excess mortality of the mentally ill. Kjelsberg et al., [32] determinated an average age of suicide of 23 years 48,4\% Aaltonen $\mathrm{K}$ et al., [33], the majority of incriminated disorders swing between personality disorders (53\%) and depressive disorders $(28 \%)$. These findings correlate perfectly with ours. The majority of inpatient women attempting suicide at Ibn Nafis hospital were diagnosed with major depressive disorder, taking a combination of antidepressants and anxiolytics for at least 3 months. Only one case of Bipolar I mania was registered, so as a schizophrenia case. It is important to highlight a similar pattern of methods between our study and Kjelsberg's, poisoning comes at first followed by drowning and hanging [32]. Pignon B et al., [34] admitted that women are more likely than men to report a psychosocial stressor prior to onset of schizophrenia. The mode of onset is similar for women and men, with two out of three experiencing gradual or insidious onset over a period of $>6$ months $(69,3 \%)$ Vera A et al., [35]. A finding that matches our result $76,3 \%$. However, women are more likely than men to have single or multiple episodes, with some recovery in between episodes, and less likely to experience chronic course of illness [34, 35]. In our study so as in other similar ones, we found that the majority of admitted women with schizophrenia have moderate positive psychotic symptoms. Acuna $\mathrm{M}$ et al., [36] showed that $20-40 \%$ of patients suffering from schizophrenia have persisting negative symptoms, severe negative symptoms during the early stages of treatment predict poor prognosis. Most of metanalysis studies proved the low level of negative symptoms of admitted women with schizophrenia, and its quick dissolving under medication. This joins our results. $50 \%$ of inpatients have mild negative symptoms when only $20 \%$ were admitted with severe negative symptoms [37]. In literature and referring to the study conducted by Olfson $\mathrm{M}$ et al., [38]. Patients with schizoaffective disorders are significantly more likely than patients with schizophrenia to receive antidepressants $(61 \%$ versus $44 \%)$, mood stabilizers $(55 \%$ versus $34,4 \%)$ and anxiolytics $(43,2 \%$ versus $35,1 \%)$. women with schizoaffective disorder are more likely than schizophrenia women to receive psychotherapy $(23,4 \%$ versus $13 \%)$ and inpatient mental health care. $(9,4 \%$ versus $6,2 \%)$. During the six months prior being admitted into the psychiatric hospital, schizoaffective women were more under antipsychotics $(60 \%)$ than women with schizophrenia $(53 \%)$. $23 \%$ of these women were under monotherapy, $13 \%$ under bitherapy of antipsychotics and only $7,9 \%$ under LAN prior the hospitalization [38]. The small sample of our study comparing to USA and Canada wide-sampled metanalysis explains the disparity of results. Clinicians have long noted the overlap of mood symptoms and psychotic symptoms. About $58 \%$ of manic patients have psychotic symptoms. $15 \%$ of depressed patients have psychotic symptoms [39]. Conversely, a depressive syndrome occurs in about $25 \%$ of people with schizophrenia [40, 41]. In our study, (83\%) of bipolar women admitted at the psychiatric hospital have psychotic features $(91,6 \%)$ of bipolar inpatients are admitted with manic episode versus 60,4\% observed in Fellinger's study [26]. 41,7\% of BID women in our case series have a comorbidity (substance's abuse in our case) Ayano G et al., [41] and Kawa et al., [42] have mentioned that the magnitude of comorbid substance use disorder is higher among women with a history of relapse and hospitalizations. 
Table-9: Comorbid substance's abuse among women suffering from bipolar disorder

\begin{tabular}{c|c|c|c|}
\hline Authors & Year & Country & Comorbld substance use \% \\
\hline Regien A et al & 1990 & USA & $60,7 \%$ \\
\hline Cagerberg T et al & 2010 & Norway & $43 \%$ \\
\hline Ayano G et al & 2017 & Ethiopia & $64 \%$ \\
\hline Our study & 2019 & Morocco & $41,7 \%$ \\
\hline
\end{tabular}

According to Hawton et al., [51] suicide deaths in major depressive disorders are associated with male gender, family history of psychiatric disorder, previous suicide attempt, depression severity, hopelessness, co-morbid anxiety and substance use disorders. Before that, Roose et al., [44] found out that the presence of psychotic features in major depressive disorders is predictive of increased risk of suicide [33, 45]. Our study joins literature with $33,6 \%$ of MDD inpatients with positive psychotic features and attempted suicides and half of them with melancholic features $(50 \%)$. According to the severity rating scale of depression HAMILTON-D. (66,3\%) of major depressive disorder inpatients are admitted for a severe major depressive episode. The rest of patients $(33,7 \%)$ are admitted for a moderate major depressive episode. This finding is close to Fisher-Kern's et al., [46] with $84,8 \%$ admitted for a severe episode while only $15,2 \%$ hospitalized for a moderate episode. The high rate of hospitalized women with a severe major depressive episode is a witness of the high tolerance eastern women of the Arab\Muslim world have against daily distress, discrimination and multiple roles in our society. A factor that delays diagnosis, therefore early treatment and follow up. According to Kessler R et al., [47] and Judd LL et al., [48] who report that Depression and anxiety exist together more often than as separate syndromes, particularly true for general anxiety disorder (GAD) and major depressive disorder, as eight out of 10 subjects with lifetime GAD also had a comorbid mood disorder during their lifetime. This finding was observed in our study with $66,7 \%$ of inpatient women admitted for MDD with anxious features (generalized anxiety disorder, panic attacks) assessed through HAM-A. Despite the availability of an increasing number of new antidepressants, treatmentresistant depression occurs in up to $30 \%$ to $40 \%$ of depressive episodes adequately treated with first-line antidepressant therapy in a psychiatric setting [49]. In literature, and according to Souery D et al., 74,4\% of admitted women with MDD were already under a therapeutic combination of antidepressants and anxiolytics for months, but admitted laters for a severe depression. A finding that is close to our result $83 \%$ [50].

\section{RECOMMENDATIONS}

- $\quad$ Fighting the general lack of awareness (mental health illiteracy) about mental illness, by suppressing the barriers to psychiatric treatments, reducing stigma and labelism via traineeship programs aiming to reinforce social skills and treatment adherence.

- Encourage women to address and speak up about positive family history of mental illness, the same as any other disease (ex: diabetes)

- Considering social/emotional support a millstone of therapy, by providing mentorship programs and support groups for family members of women living with mental disorders

- Promoting serious education efforts that target everyone in the community, especially family members, by explaining that mental disorders are not a weakness but only a chemical imbalance that requires family's management of residual symptoms, acute episodes and constant irritability, via simulation sessions and coping skills

- Providing recreational outlets for women, such as community centers offering daily activities (culinary activities, knitting, gardening, preparing résumés for job searching, managing finances and learning to cope with common stressors). These activities improve their individual ability to cope and thereby improve the emotional wellness

- Emotional, relational and sexual dimensions are important criteria to consider when prescribing treatments

- Spirituality constitutes a huge milstone in the arab community, especially among women. The adherence to prayers and different forms of meditation helps diminishing anxiety symptoms and is considered a coping method against day to day distress

- Maintain a solid, individual therapeutic alliance.

- Promoting a non pharmacological treatment, CBT, psychoeducation, insight and cognitive remediation. 


\section{CONCLUSION}

Women suffering from schizophrenia represent half of hospitalized population, bipolar disorder and major depressive disorder inpatients get admitted mostly because of the psychotic features. The stigma that labels women with psychiatric disorders gets in the way of treatment adherence, follow up with psychotherapies and belief that medication is the road to wellbeing. Low economical level alongside with poor education are noticed to be factors that increase acute episodes, why not onset of disorder. The high rate of ill admitted women under no treatment, but with a positive toxic habit complicates the course of disorder and its management. It is important to instore a scientific-based culture of psychotherapies (individual or per group), that impacts not only one's thoughts and coping styles but also the global functioning and personal ways of dealing with acute phases, treatment side effects and various changes in ideas or behavior.

\section{REFERENCES}

1. Repper J, Perkins R, Owen S. 'I wanted to be a nurse... but I didn't get that far': women with serious ongoing mental health problems speak about their lives. Journal of Psychiatric and Mental Health Nursing. 1998 Dec;5(6):505-13.

2. Faris N, Baroud E, Al Hariri M, Bachir R, ElKhoury J, Batley NJ. Characteristics and dispositional determinants of psychiatric emergencies in a University Hospital in Beirut. Asian journal of psychiatry. 2019 Apr 1;42:42-7.

3. Ferrari AJ, Norman RE, Freedman G, Baxter AJ, Pirkis JE, Harris MG, Page A, Carnahan E, Degenhardt L, Vos T, Whiteford HA. The burden attributable to mental and substance use disorders as risk factors for suicide: findings from the Global Burden of Disease Study 2010. PloS one. 2014;9(4):91-93.

4. Belghazi D, Moussaoui D, Kadri N. Spécificités épidémiologiques, cliniques et culturelles des patients hospitalisés au centre psychiatrique universitaire Ibn-Rochd de Casablanca. InAnnales Médico-psychologiques, revue psychiatrique 2016 Mar 1:174(2):100-104.

5. Castro SA, Furegato AR, Santos JL. Sociodemographic and clinical characteristics of psychiatric re-hospitalizations. Revista latinoamericana de enfermagem. 2010 Aug;18(4):800-8.

6. Cloitre M, Cancienne J, Brodsky B, Dulit R, Perry SW. Memory performance among women with parental abuse histories: Enhanced directed forgetting or directed remembering?. Journal of Abnormal Psychology. 1996 May;105(2):204-211.

7. Cochrane R, Stopes-Roe M. Women, marriage, employment and mental health. The British Journal of Psychiatry. 1981 Nov;139(5):373-81.

8. El Sayed SM, Maghraby MM, Hafeiz HB, Buckley MM. Psychiatric diagnostic categories in
Saudi Arabia. Acta Psychiatrica Scandinavica. 1986 Dec;74(6):553-4.

9. Calzeroni A, Conte G, Pennati A, Vita A, Sacchetti E. Celibacy and fertility rates in patients with major affective disorders: the relevance of delusional symptoms and suicidal behaviour. Acta psychiatrica scandinavica. 1990 Oct;82(4):309-10.

10. Klein DN, Schatzberg AF, McCullough JP, Dowling F, Goodman D, Howland RH, Markowitz JC, Smith C, Thase ME, Rush AJ, LaVange L. Age of onset in chronic major depression: relation to demographic and clinical variables, family history, and treatment response. Journal of Affective Disorders. 1999 Oct 1;55(2-3):149-57.

11. Maharlouei N, Hoseinzadeh A, Ghaedsharaf E, Zolfi H, Arab P, Farahmand Z, Hallaj M, Fazilat S, Heidari ST, Joulaei H, Karbalaie F. The mental health status and associated factors affecting underprivileged Iranian women. Asian journal of psychiatry. 2014 Dec 1;12:108-12.

12. Roohafza H, Sadeghi M, Shirani S, Bahonar A, Mackie M, Sarafzadegan N. Association of socioeconomic status and life-style factors with coping strategies in Isfahan Healthy Heart Program, Iran. Croatian medical journal. 2009 Aug 15;50(4):380-6.

13. Comacchio C, Howard LM, Bonetto C, Parrino RL, Furlato K, Semrov E, Preti A, Mesiano L, Neri G, De Girolamo G, de Santi K. The impact of gender and childhood abuse on age of psychosis onset, psychopathology and needs for care in psychosis patients. Schizophrenia research. 2019 Aug 1;210:164-71.

14. Adachi N, Hara T, Oana Y, Matsuura M, Okubo $\mathrm{Y}$, Akanuma $\mathrm{N}$, Ito $\mathrm{M}$, Kato $\mathrm{M}$, Onuma $\mathrm{T}$. Difference in age of onset of psychosis between epilepsy and schizophrenia. Epilepsy research. 2008 Feb 1;78(2-3):201-6.

15. Albus M, Maier W. Lack of gender differences in age at onset in familial schizophrenia. Schizophrenia Research. 1995 Dec 1;18(1):51-7.

16. Alda M, Ahrens B, Lit W, Dvorakova M, Labelle A, Zvolsky P, Jones B. Age of onset in familial and sporadic schizoph4. 4. renia. Acta Psychiatrica Scandinavica. 1996 Jun;93(6):447-50.

17. Arajärvi R, Varilo $T$, Haukka J, Suvisaari J, Suokas J, Juvonen H, Muhonen M, Suominen K, Hintikka J, Schreck M, Tuulio-Henriksson A. Affective flattening and alogia associate with the familial form of schizophrenia. Psychiatry research. $2006 \mathrm{Feb} 28 ; 141(2): 161-72$.

18. Konnecke R, Hafner H, Maurer K, Loffler W, an der Heiden W. Main risk factors for schizophrenia: increased familial loading and pre-and peri-natal complications antagonize the protective effect of oestrogen in women. Schizophrenia research. 2000;1(44):81-93.

19. Bromberger JT, Kravitz HM, Youk A, Schott LL, Joffe H. Patterns of depressive disorders across 13 years and their determinants among midlife 
women: SWAN mental health study. Journal of affective disorders. 2016 Dec 1;206:31-40.

20. Rees E, O’Donovan MC, Owen MJ. Genetics of schizophrenia. Current Opinion in Behavioral Sciences. 2015 Apr 1;2:8-14.

21. Bohacek J, Mansuy IM. Epigenetic inheritance of disease and disease risk. Neuropsychopharmacology. 2013 Jan;38(1):22036.

22. Rossegger A, Wetli N, Urbaniok F, Elbert T, Cortoni F, Endrass J. Women convicted for violent offenses: Adverse childhood experiences, low level of education and poor mental health. BMC psychiatry. 2009 Dec;9(1):81.

23. Skinner W, O'Grady CP, Bartha C, Parker C. Les troubles concomitants de toxicomanie et de santé mentale. Centre de toxicomanie et de santé mentale; 2004.

24. Lambert M, Conus P, Lubman DI, Wade D, Yuen $\mathrm{H}$, Moritz S, Naber D, McGorry PD, Schimmelmann BG. The impact of substance use disorders on clinical outcome in 643 patients with first- episode psychosis. Acta Psychiatrica Scandinavica. 2005 Aug;112(2):141-8.

25. Sevy S, Robinson DG, Holloway S, Alvir JM, Woerner MG, Bilder R, Goldman R, Lieberman J, Kane J. Correlates of substance misuse in patients with first- episode schizophrenia and schizoaffective disorder. Acta Psychiatrica Scandinavica. 2001 Nov;104(5):367-74.

26. Fellinger M, Waldhör T, Blüml V, Williams N, Vyssoki B. Influence of gender on inpatient treatment for bipolar disorder: an analysis of 60,607 hospitalisations. Journal of affective disorders. 2018 Jan 1;225:104-7.

27. Newman L, Harris V, Evans LJ, Beck A. Factors associated with length of stay in psychiatric inpatient services in London, UK. Psychiatric Quarterly. 2018 Mar 1;89(1):33-43.

28. Tulloch AD, Khondoker MR, Fearon P, David AS. Associations of homelessness and residential mobility with length of stay after acute psychiatric admission. BMC psychiatry. 2012 Dec;12(1):121.

29. Seeman MV. The role of estrogen in schizophrenia. Journal of Psychiatry and Neuroscience. 1996 Mar;21(2):123.

30. Ridgely $\mathrm{MS}$, Goldman $\mathrm{HH}$, Willenbring $\mathrm{M}$. Barriers to the care of persons with dual diagnoses: organizational and financing issues. Schizophrenia Bulletin. 1990 Jan 1;16(1):123-32.

31. Drake RE, Mueser KT. Alcohol-use disorder and severe mental illness. Alcohol Health and Research World. 1996;20(2):87.

32. Kjelsberg E, Neegaard E, Dahl AA. Suicide in adolescent psychiatric inpatients: incidence and predictive factors. Acta Psychiatrica Scandinavica. 1994 Apr;89(4):235-41.

33. Aaltonen KI, Isometsä E, Sund R, Pirkola S. Risk factors for suicide in depression in Finland: firsthospitalized patients followed up to 24 years. Acta
Psychiatrica Scandinavica. 2019 Feb;139(2):15463.

34. Pignon B, Schürhoff F, Szöke A, Geoffroy PA, Jardri R, Roelandt JL, Rolland B, Thomas P, Vaiva G, Amad A. Sociodemographic and clinical correlates of psychotic symptoms in the general population: findings from the MHGP survey. Schizophrenia research. 2018 Mar 1;193:336-42.

35. Morgan VA, Castle DJ, Jablensky AV. Do women express and experience psychosis differently from men? Epidemiological evidence from the Australian National Study of Low Prevalence (Psychotic) Disorders. Australian and New Zealand Journal of Psychiatry. 2008 Jan $1 ; 42(1): 74-82$.

36. Acuña MJ, Martín JC, Graciani M, Cruces A, Gotor F. A comparative study of the sexual function of institutionalized patients with schizophrenia. The journal of sexual medicine. 2010 Oct 1;7(10):3414-23.

37. Ring N, Tantam D, Montague L, Newby D, Black $\mathrm{D}$, Morris J. Gender differences in the incidence of definite schizophrenia and atypical psychosisfocus on negative symptoms of schizophrenia. Acta Psychiatrica Scandinavica. 1991 Dec;84(6):489-96.

38. Olfson M, Marcus SC, Wan GJ. Treatment patterns for schizoaffective disorder and schizophrenia among Medicaid patients. Psychiatric services. 2009 Feb;60(2):210-6.

39. Goodwin FK, Jamiso KR. Manic-depressive illness. Oxford University Press. 1990.

40. Kempf L, Hussain N, Potash JB. Mood disorder with psychotic features, schizoaffective disorder, and schizophrenia with mood features: trouble at the borders. International Review of Psychiatry. 2005 Feb 1;17(1):9-19.

41. Varo C, Murru A, Salagre E, Jiménez E, Solé B, Montejo L, Carvalho AF, Stubbs B, Grande I, Martínez-Arán A, Vieta E. Behavioral addictions in bipolar disorders: A systematic review. European Neuropsychopharmacology. 2019 Jan 1;29(1):76-97.

42. Ayanoand G, Duko B. Relapse and hospitalization in patients with schizophrenia and bipolar disorder at the St Amanuel Mental Specialized Hospital, Addis Ababa, Ethiopia: A comparative quantitative cross-sectional study Neuropsychiatric Disease and Treatment 2017,13; 1527-1531.

43. Kawa I, Carter JD, Joyce PR, Doughty CJ, Frampton CM, Elisabeth Wells J, Walsh AE, Olds RJ. Gender differences in bipolar disorder: age of onset, course, comorbidity, and symptom presentation. Bipolar disorders. 2005 Apr;7(2):119-25.

44. Roose SP, Glassman AH, Walsh BT, Woodring S, Vital-Herne J. Depression, delusions, and suicide. Am J Psychiatry. 1983 Sep;140(9):1159-62.

45. Whitford TJ, Kubicki M, Schneiderman JS, O'Donnell LJ, King R, Alvarado JL, Khan U, 
Markant D, Nestor PG, Niznikiewicz M, McCarley RW. Corpus callosum abnormalities and their association with psychotic symptoms in patients with schizophrenia. Biological psychiatry. 2010 Jul 1;68(1):70-7.

46. Diamond D, Levy KN, Clarkin JF, Fischer-Kern M, Cain NM, Doering S, Hörz S, Buchheim A. Attachment and mentalization in female patients with comorbid narcissistic and borderline personality disorder. Personality Disorders: Theory, Research, and Treatment. 2014 Oct;5(4):428-433.

47. Kessler RC, Berglund P, Demler O, Jin R, Koretz D, Merikangas KR, Rush AJ, Walters EE, Wang PS. The epidemiology of major depressive disorder: results from the National Comorbidity Survey Replication (NCS-R). Jama. 2003 Jun 18;289(23):3095-105.

48. Judd LL, Akiskal HS, Maser JD, Zeller PJ, Endicott J, Coryell W, Paulus MP, Kunovac JL, Leon AC, Mueller TI, Rice JA. A prospective 12- year study of subsyndromal and syndromal depressive symptoms in unipolar major depressive disorders. Archives of general psychiatry. 1998 Aug 1;55(8):694-700.

49. Souery D, Oswald P, Massat I, Bailer U, Bollen J, Demyttenaere K, Kasper S, Lecrubier Y, Montgomery S, Serretti A, Zohar J. Clinical factors associated with treatment resistance in major depressive disorder: results from a European multicenter study. Journal of Clinical Psychiatry. 2007;68(7):1062-70.

50. Petersen T, Papakostas GI, Posternak MA, Kant A, Guyker WM, Iosifescu DV, Yeung AS, Nierenberg AA, Fava M. Empirical testing of two models for staging antidepressant treatment resistance. Journal of clinical psychopharmacology. 2005 Aug 1;25(4):336-41.

51. Hawton K, i Comabella CC, Haw C, Saunders K. Risk factors for suicide in individuals with depression: a systematic review. Journal of affective disorders. 2013 May 1;147(1-3):17-28. 